\section{Ana Šitina}

Sveučilište u Zadru, Odjel za povijest umjetnosti

Prethodno priopćenje / Preliminary communication UDK / UDC: 75.057(497.5 Zadar)

15. 6. 2014.
Nova razmišljanja o kodeksima zadarskog opata Deodata Veniera*

Ključne riječi: renesansa, Zadar, kodeksi opata Deodata Veniera, mletačka minijatura, ferrarska minijatura Keywords: Renaissance, Zadar, codices of Abbot Deodat Venier, Venetian illuminations, Ferrara illuminations

Članak obrađuje srodnost renesansnih iluminacija svetokrševanskih kodeksa, nastalih po nalogu zadarskog opata Deodata Veniera, s ferrarskom sitnoslikarskom školom. Kodeksi su se u starijoj literaturi povezivali s mletačkim krugom, a s opusom Picova Majstora dovode se u vezu u novije vrijeme te se razrađuje problematika povezivanja s konkretnim iluminatorima sobzirom na to da materijal pokazuje dodirne točke isključivo na općoj razini.

U kontekstu sačuvanih iluminiranih rukopisa u Hrvatskoj veliko značenje imaju kodeksi nastali za samostan sv. Krševana u Zadru čiji stilski izraz predstavlja vrhunac renesansne iluminacije nastale za naše naručitelje. Dolaskom pod upravu opata Deodata Veniera ${ }^{1} 1459$. godine samostan je obnovio svoje djelovanje na raznim poljima² te doživio procvat upravo u pogledu sitnoslikarske produkcije. $\mathrm{U}$ to je vrijeme posjedovao arhiv, aktiviran je bio rad skriptorija, obnavljala se opatijska dvorana, postavljali temelji za zvonik te izrađivali razni dekorativni dodaci na samostanu, a tada je Venier dao izraditi i četiri obredne knjige na kojima se najsnažnije osjeća duh nove umjetnosti koju naručuje okupljajući oko sebe niz humanista s kojima surađuje na kulturnom procvatu samostana i grada. ${ }^{3}$ Međutim, Venierovom smrću 1488. godine završio je i sjajni trenutak u povijesti samostana kojeg je opet bio zahvatio komendatorni režim, a za prvog opata nove uprave bio je postavljen Bernard de Rossi iz Parme. ${ }^{4}$ Osim četiri svetokrševanska kodeksa, niz je drugih iluminiranih rukopisa u to vrijeme nastalo ili je naručeno za Zadar, a brojni su rukopisi i kolali po gradu koji je vrvio došljacima; međutim, kako se navedeni kodeksi koji su nastali za zadarske naručitelje više ne nalaze u Zadru, a oni koji su sačuvani ${ }^{5}$ najvjerojatnije nisu domaće proveni- jencije te se o njoj samo naslućuje, teško je rekonstruirati stvarnu sliku tadašnjeg razvoja iluminacije u gradu.

Godine 1830. Dvorskoj knjižnici u Beču Zadranin Gianbattista de Ponte prodao je Evanđelistar i Epostolar ${ }^{6}$ te oni u domaćoj literaturi neko vrijeme nisu bili poznati premda su bili evidentirani u starom katalogu rukopisa Nacionalne knjižnice u Beču 1863., a 1931. godine H. J. Herman ih je opisao navodeći Evanđelistar kao talijansko djelo. ${ }^{7} \mathrm{Za}$ njih se pretpostavlja da su nastali u skriptoriju svetokrševanskog samostana u drugoj polovini 15. stoljeća, a za Misal se do danas ne zna kakva mu je bila sudbina. On je u 19. stoljeću bio u posjedu šibenskog biskupa, Zadranina Ivana Berčića, koji ga je poklonio knjižnici Zmajevićeva sjemeništa u Zadru odakle je nestao 1921. godine. ${ }^{8} \mathrm{U}$ katalogu izložbe Minijatura u Jugoslaviji, ${ }^{9}$ o rukopisima se iznosi samo kratko priopćenje, a spominje ih i I. Petricioli u knjizi Zadar pod mletačkom upravom 1987. ${ }^{10}$ Detaljan opis donosi J. Kolanović 1983. godine ${ }^{11}$ te 2006. godine i E. Hilje u knjizi Umjetnička baština Zadarske nadbiskupije - Slikarstvo, ${ }^{12} \mathrm{dok}$ 2012. godine o njima piše i M. Pelc. ${ }^{13}$ Izgled Misala poznat je zahvaljujući fotografijama i opisima G. Sabalicha ${ }^{14}$ i H. Folnesicsa. ${ }^{15}$ Uz navedene, o Misalu su pisali brojni autori poput C. F. Bianchija, V. Brunellija, A. Dudana i Lj. Kara- 


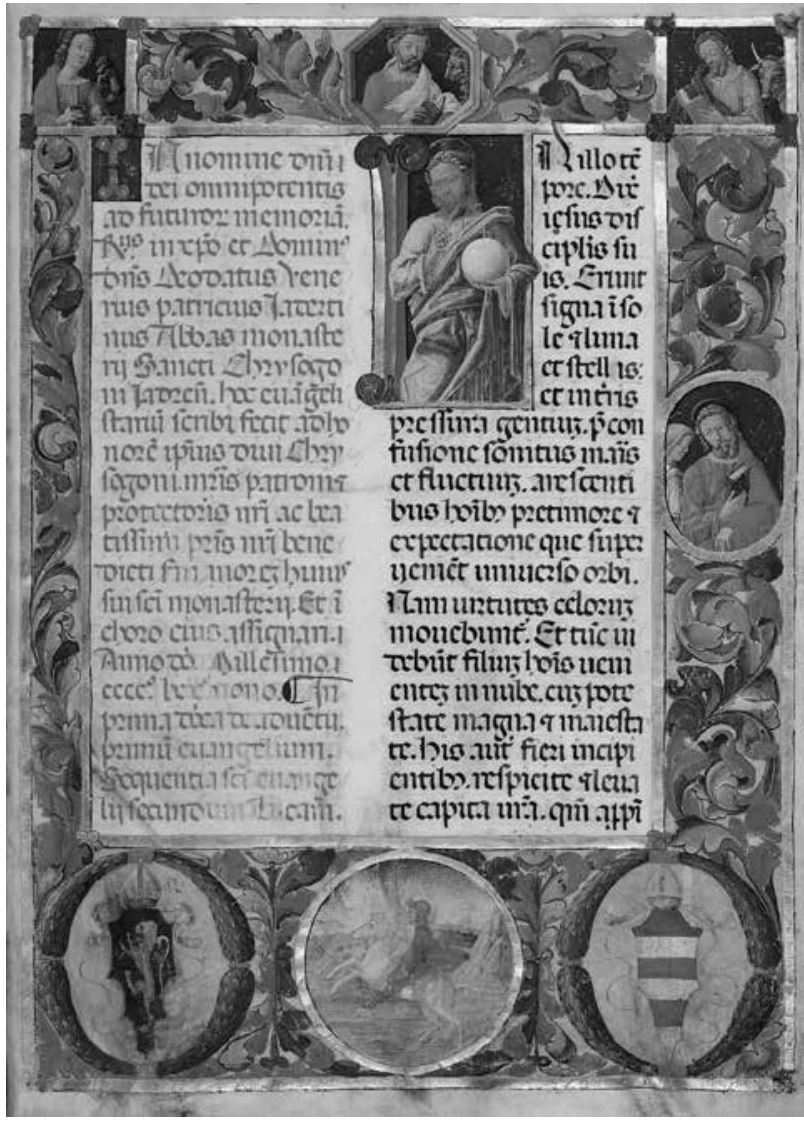

1. Albert Borgodensis (?), Evanđelistar opata Deodata Veniera, 1479.-1491., Osterreichische Nationalbibliothek, Beč (izvor: Fototeka Zavoda za zaštitu spomenika, Zadar) / Albert Borgodensis (?), Evangelistary of Abbot Deodat Venier, 14791491, Österreichische Nationalbibliothek, Vienna (source: Photo library of the Conservation Department, Zadar)

mana. Za razliku od tri Venierova kodeksa koji su ukrašeni bogatim figuralnim dionicama, Ritual koji se danas čuva u Kaptolskoj knjižnici u Zadru, osim vegetabilno ukrašenih inicijala, nema figuralnih ukrasa. ${ }^{16} \mathrm{Njega}$ spominje Ivo Petricioli, ${ }^{17}$ a temeljitiji opis donose J. Kolanović ${ }^{18}$ i E. Hilje. ${ }^{19}$ $\mathrm{U}$ ovom radu Venierovi kodeksi nisu nepotrebno opisivani jer su njihove detaljne analize objavljene u relativno novije vrijeme od strane drugih istraživača koji su se bavili njihovom problematikom. ${ }^{20}$ Evandelistar, Epistolar i Ritual započeti su 1479. godine, a Misal 1480., dok za Evanđelistar postoji natpis koji svjedoči da je dovršavan još i 1491. godine u Veneciji; kao godina dovršetka ostala tri kodeksa uzima se 1488., godina smrti opata Deodata Veniera. Sva tri figuralno ukrašena kodeksa na prvoj su stranici imali gotovo identičnu bilješku o nabavi, a za Ritual, kome je istrgnut prvi folij, na osnovi ostalih, također se pretpostavlja postojanje ispisanog naloga o pisanju rukopisa kao i bogatija dekoracija.

Za sva tri figuralno iluminirana kodeksa, prema gotovo identičnim natpisima u uvodnom tekstu, jasno se zna da su nastali po nalogu opata Deodata Veniera i za potrebe

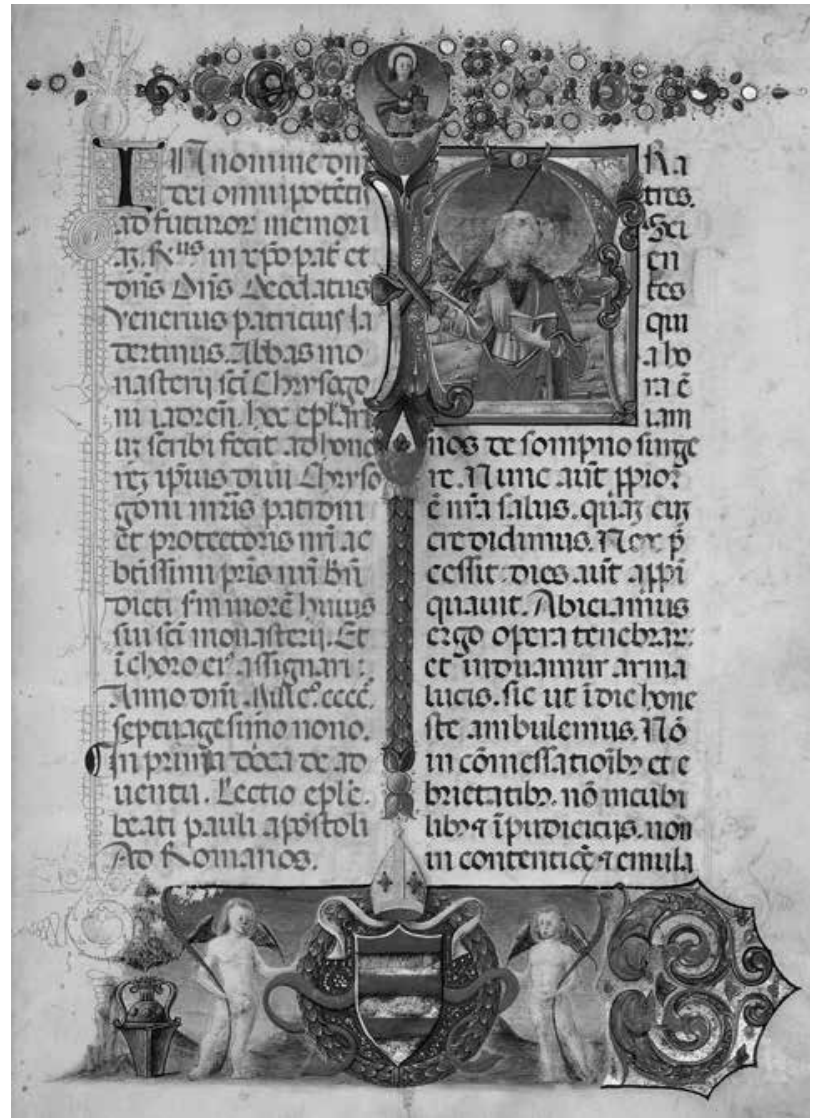

2. Nepoznati minijaturist, Epistolar opata Deodata Veniera, 1479.1488., Österreichische Nationalbibliothek, Beč (izvor: Fototeka Zavoda za zaštitu spomenika, Zadar) / Unknown miniaturist, Epistolary of Abbot Deodat Venier, 1479-1488, Österreichische Nationalbibliothek, Vienna (source: Photo library of the Conservation Department, Zadar) samostana sv. Krševana u Zadru, što dodatno potvrđuje oslikani lik sv. Krševana koji se javlja na sva tri kodeksa sa sačuvanim figuralnim oslicima, te opatovi grbovi. $S$ druge strane, nije posve jasno gdje su nastali i tko ih je oslikao. Jedini podatak o tome jest bilješka na foliju 113 Evandelistara u kojoj stoji da ga je načinio magister Albertus Borgodiensis. Kako je najčešće jedna ruka pisala tekst, a druga izrađivala ukrase, teško je zaključiti je li navedeni magister Albert Borgodiensis bio i autor nekih iluminacija u Evandelistaru. U završnoj bilješci na kraju Evanđelistara (folij 123) piše da je njegov osnovni tekst završen 16. srpnja 1489. godine kada je Albertu Borgodiensisu troškove rada isplatio nasljednik opata Deodata Veniera, Bernardo Rossi. Međutim, osim toga, postoje u Evanđelistaru i naknadne bilješke koje svjedoče o tome da je ukrašavanje teksta potrajalo i dulje, do 1491. godine. Na foliju 108r tako stoji, već spomenuti, natpis: »1.4.91. VELOCITER IN VENECIA $«{ }^{21}$ a iste te godine, na foliju 113, također unutar inicijala » « u dvije vertikalne crte upisan je i potpis izrađivača teksta: »ALBERTUS FE(cit) A DI 15. LUIO 1491. ${ }^{22}$ Nije poznato o kakvim je okolnosti- 


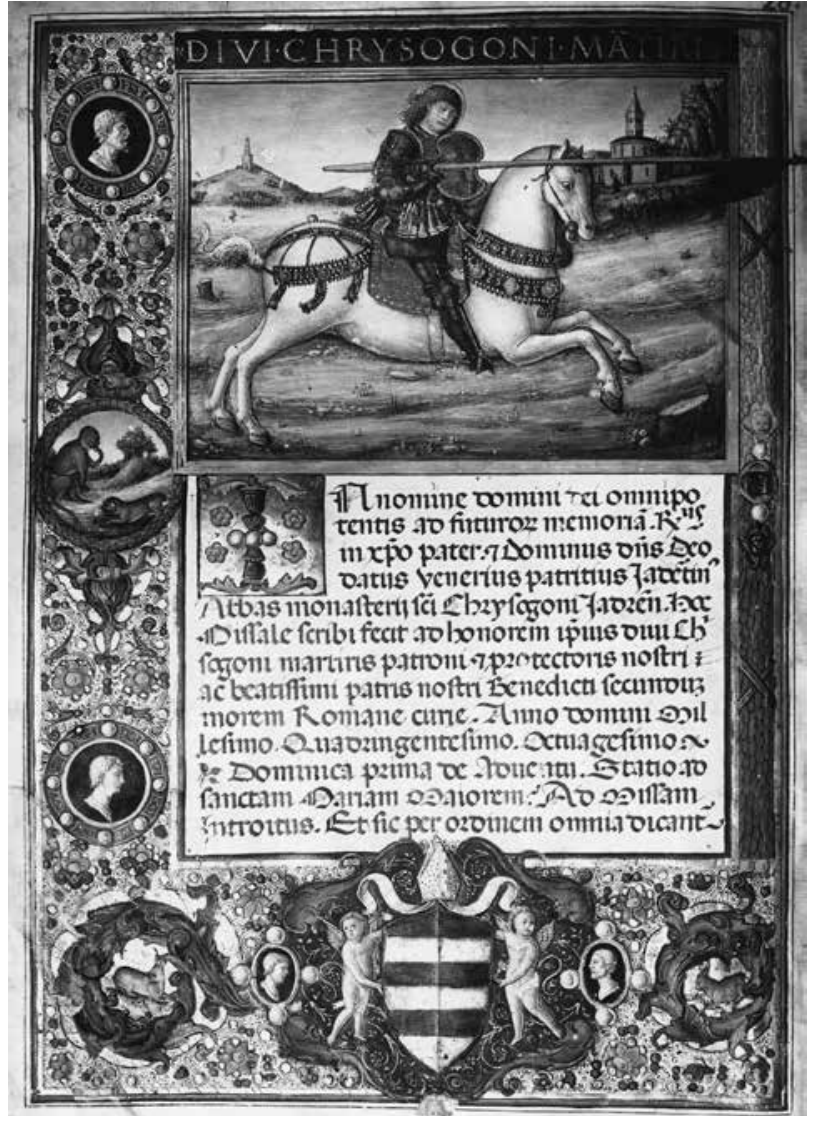

3. Nepoznati minijaturist, Misal opata Deodata Veniera, 1480.1488., nepoznata lokacija, nekoć u knjižnici sjemeništa Zmajević u Zadru, folij 1 (izvor: Fototeka Zavoda za zaštitu spomenika, Zadar) / Unknown miniaturist, Missal of Abbot Deodat Venier, 1480-1488, unknown location, previously in the library of the Zmajević Seminary in Zadar, folio 1 (source: Photo library of the Conservation Department, Zadar)

ma riječ, no nije li neobično da se pisar potpisuje dvaput, a iluminator nijednom. Je li možda riječ o jednoj osobi? To, u svakom slučaju, nije nemoguće, prisjetimo li se, takva pojava je u to vrijeme kod iluminacije glagoljaških rukopisa posve uobičajena. Također možemo primijetiti i pedantnost potrebe da se sve u Evanđelistaru dokumentira pa se bilježi i naknadno dovršen dio. Ne bi li se, u tom slučaju, i iluminator imao potrebu potpisati ili bi se to od njega očekivalo ako nije riječ o istoj osobi? Pretpostavimo li da je potpisani Albert iz Burgundije i iluminator, likovne odlike iluminirane naslovne stranice Evandelistara išle bi tomu u prilog, jer se uz odlike mletačkog i padovanskog slikarstva osjeća sjevernjački »štih " primjetan u oštrom svjetlu te naglasku na linearnom tretmanu likova koji se naročito očituje u fino izvučenim, valovitim crnim linijama na zlatnoj podlozi kose, lica i draperije te na simbolima evanđelista. Fina, tanka, samo zlatnom linijom izvedena aureola te draperija lomljena pod pravim kutom također je nešto blisko sjevernjačkom ukusu kao i hladni, ljubičasti tonovi u kombinaciji s kričavom crvenom i žutom bojom na tamnoplavoj pozadini. Biljna

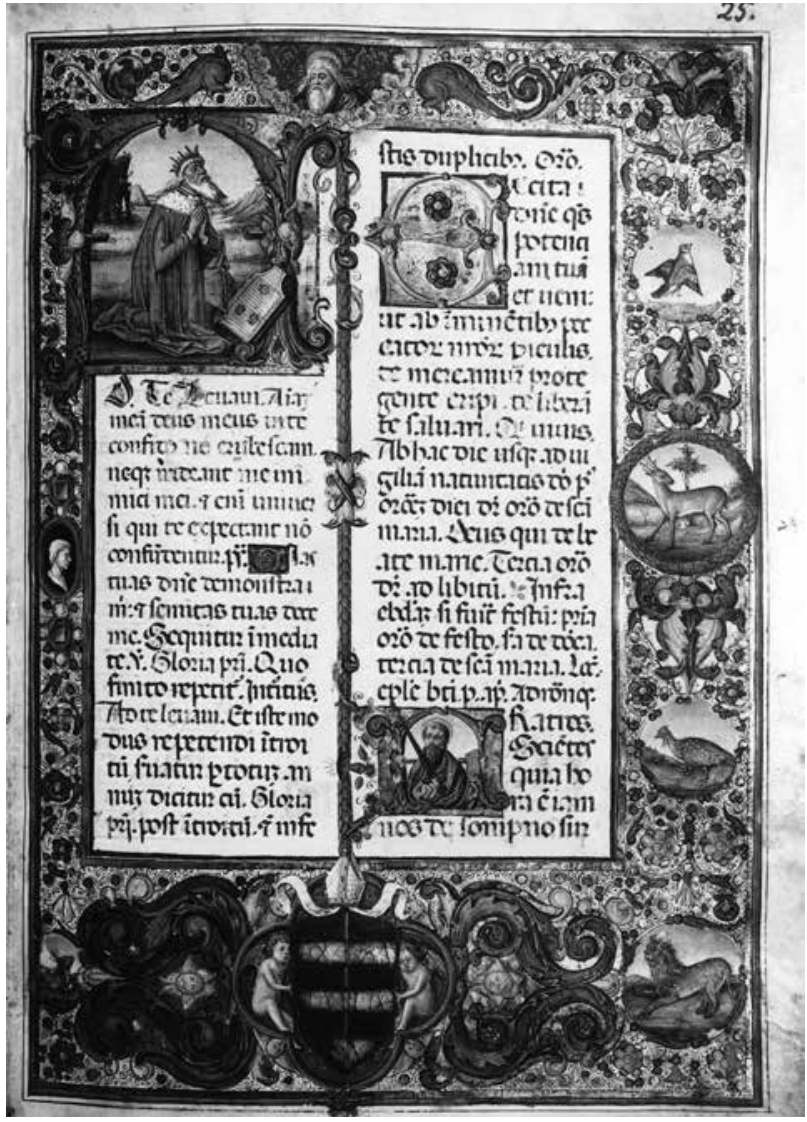

4. Nepoznati minijaturist, Misal opata Deodata Veniera, 1480.1488., nepoznata lokacija, nekoć u knjižnici sjemeništa Zmajević u Zadru, folij 2 (izvor: Fototeka Zavoda za zaštitu spomenika, Zadar) / Unknown miniaturist, Missal of Abbot Deodat Venier, 1480-1488, unknown location, previously in the library of the Zmajević Seminary in Zadar, folio 2 (source: Photo library of the Conservation Department, Zadar)

povijuša marginalne dekoracije također je bliža sjevernjačkom nego talijanskom ukusu. Određenu bliskost pokazuje biljna povijuša na oslikanim dijelovima Biblie Italice Franca dei Russija. ${ }^{23}$ Možda je Albert, uz ispis teksta, iluminator tek kaligrafskog dijela Evanđelistara kako pretpostavlja M. Pelc. ${ }^{24}$ Kako su na naslovnoj stranici Evandelistara oslikani grbovi obojice svetokrševanskih opata, očito je da su iluminacije nastale nakon smrti opata Deodata Veniera (1488.) i nakon dovršetka pisanja teksta 1489., kako stoji u bilješci na posljednjem foliju 123 u kojoj se iznosi podatak o dovršenju teksta i isplati novca pisaru. Da je Albert samo pisar, ne bi li onda i uz njegov potpis stajala ista 1489 . godina? S obzirom na to da uz njegov potpis stoji godina 1491., očito je da je Albert još dvije godine nešto radio na kodeksu, odnosno da ga je ukrašavao. Prema bilješci na foliju 108 zabilježen je i podatak da je žurno završen u Veneciji, ali se i dalje ne zna gdje je prije pisan i ukrašavan. S obzirom na jasnu stilsku razliku medaljona s prikazom sv. Krševana na konju koji se nalazi u središtu donjega marginalnog polja u odnosu na ostatak iluminirane stranice, bilješka zabilježena na foliju 


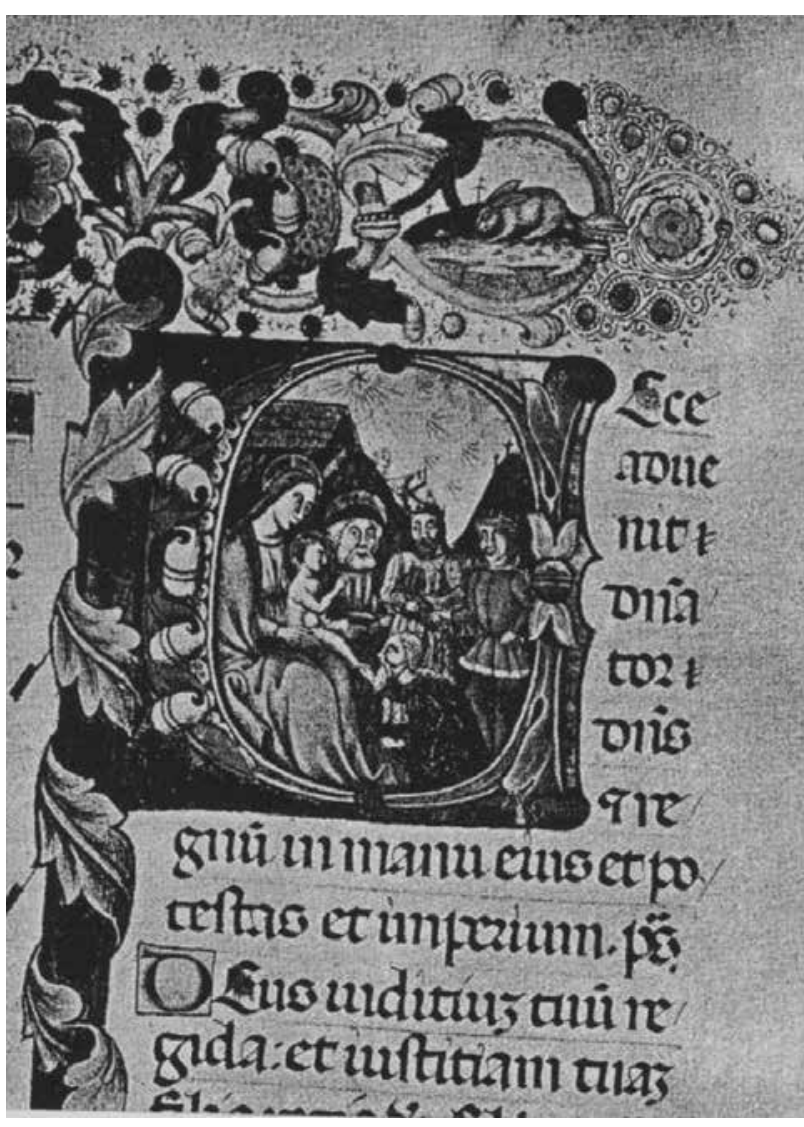

5. Nepoznati minijaturist, Misal opata Deodata Veniera, 1480.-1488., nepoznata lokacija, nekoć u knjižnici sjemeništa Zmajević u Zadru, folij 38, detalj Poklonstvo kraljeva (preuzeto iz: Giuseppe Sabalich, Le miniature antiche di Zara, 1909.) / Unknown miniaturist, Missal of Abbot Deodat Venier, 1480-1488, unknown location, previously in the library of the Zmajević Seminary in Zadar, folio 38, detail, Adoration of the Magi (source: Giuseppe Sabalich, Le miniature antiche di Zara, 1909)

108 »VELOCITER IN VENECIA« možda znači dovršenje upravo toga segmenta na naslovnoj stranici koji pokazuje odlike tipične za mletačko slikarstvo toga vremena.

Iako je razvidno da su ih izradile različite ruke, žarki i izražajni kolorit te crtež i način korištenja svjetla odaju srodnost ukusa Evanđelistara i Epistolara. Da je riječ o dva različita majstora, najjasnije se očituje u oblikovanju figuralnih dionica. Na naslovnoj stranici Evandelistara lik sv. Krševana na konju prikazan u medaljonu na donjoj margini okupan toplim svjetlom i smješten u oskudan krajolik, kao što je već spomenuto, odskače od nešto više koloristički tretiranoga prevladavajućeg oslika bez pozadinske dubine, a u krajoliku toga tipa i takvih karakteristika smješteni su i likovi sv. Pavla te Venierov grb s puttima u Epistolaru. Osim krajolika, i način oblikovanja unutar medaljona blizak je ruci koja radi na Epistolaru. Moguće je da je ta ruka i dovršavala medaljon. S obzirom na sličan ukus i opisane karakteristike, za ova dva kodeksa naručena u isto vrijeme od strane istog naručitelja, mogli bismo pretpostaviti da su naručena i od

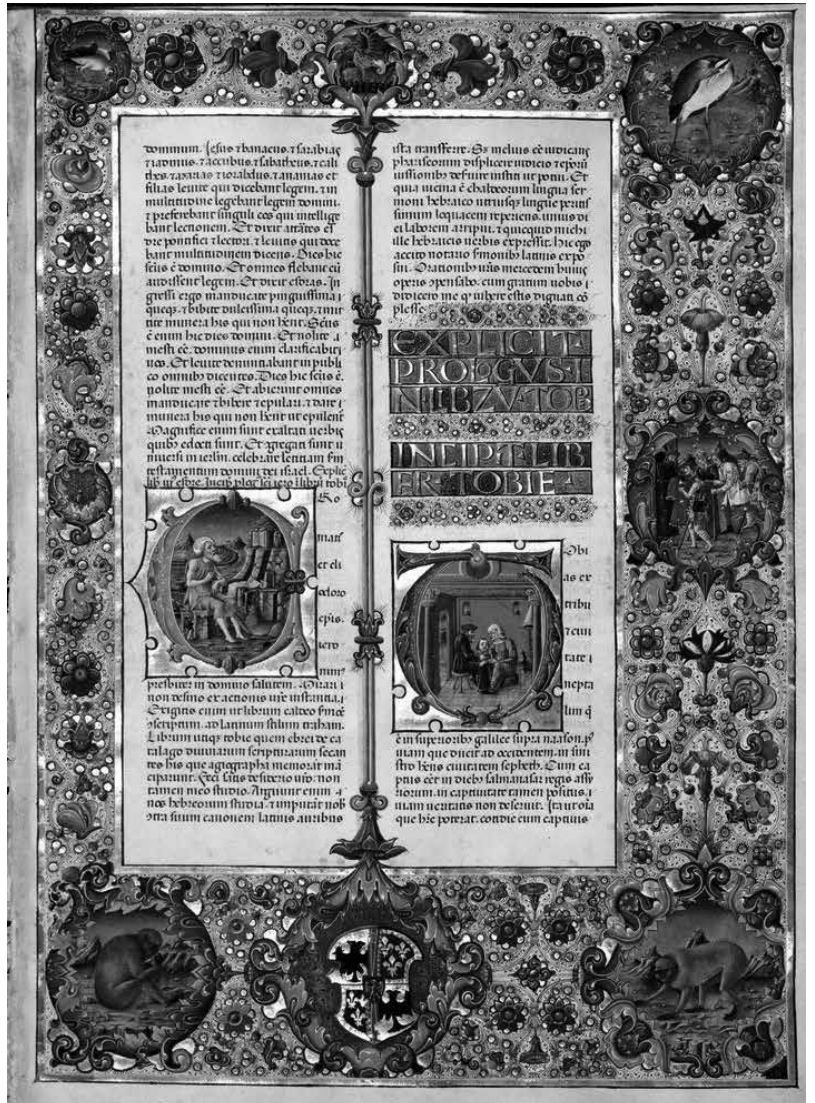

6. Usporedba s dekoracijom Misala: Biblija Borsa d'Este, folij 424, 1455.-1461., Biblioteca Estense u Modeni (Ms. Lat. 422-423) (izvor: http://www.wdl.org/en/item/9910/view/1/1/; 19. 6. 2013.) / Comparation with the Missal decoration: Bible of Borso d'Este, folio 424, 1455-1461, Biblioteca Estense, Modena (Ms. Lat. 422-423), (source: http://www.wdl.org/en/item/9910/view/1/1/, 19 June 2013)

iste radionice u kojoj vlada sličan ukus, ali djeluje nekoliko iluminatora, od kojih se ovdje razabire jedan mogućega sjevernjačkog školovanja koji djeluje u Veneciji te drugi mletačkog iskustva. Ako su ta dva iluminatora zaista djelovala unutar iste radionice u kojoj su pisani Venierovi kodeksi, nije neobično da je jedan dovršio dio drugoga. Međutim, to bi bila samo hipoteza temeljena na stilskoj analizi i činjenici da je oba kodeksa naručio isti opat i u istom razdoblju te da oba posjeduju identičan sadržaj uvodnog teksta, ${ }^{25}$ a stil jednog majstora prepoznajemo na segmentu drugog oslika.

Epistolar je najvjerojatnije završen za Venierova života jer je na naslovnoj stranici iluminiran i svečano istaknut samo njegov grb, sukladno s tim vjerojatno je i pisar završio posao prije opatove smrti 1488. godine jer dosad nije pronađena bilješka da je netko drugi isplatio posao pisaru kako je to slučaj kod Evanđelistara. ${ }^{26} \mathrm{U}$ tom uvodnom tekstu ističe se da su Evanđelistar i Epistolar izrađeni prema običaju svetokrševanskog samostana, dok za Misal stoji da je izrađen prema običaju Rimske kurije. U tome je, kao i u 


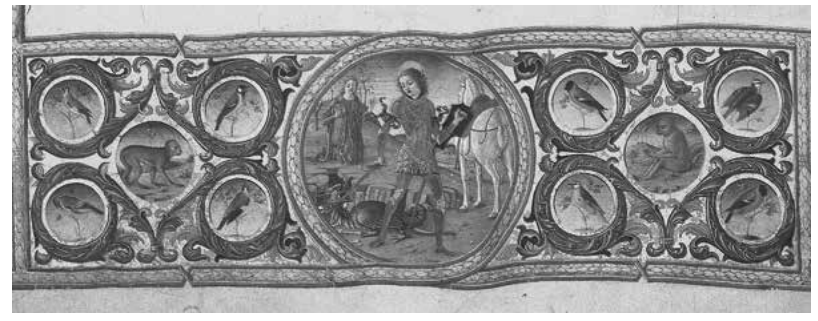

7. Usporedba s dekoracijom Misala: Martino da Modena, Antifonario VII, C. 5v, Sveti Juraj i zmaj, 1478.-1486., Muzej katedrale, Ferrara (izvor: http://www.artecultura.fe.it/1766/ percorso-espositivo; 19. 6. 2013.) / Comparation with the Missal decoration: Martino da Modena, Antifonario VII, C. 5v, St George and the Dragon, 1478-1486, Cathedral Museum, Ferrara (source: http://www.artecultura.fe.it/1766/percorso-espositivo 19 June 2013)

činjenici da je započet godinu dana kasnije, razlika između Evanđelistara i Epistolara od Misala čije figuralne dionice najviše srodnosti pokazuju s tipičnim mletačkim ukusom i načinom oblikovanja.

U radu Picov Majstor i kodeksi zadarskog opata Deodata Veniera M. Pelc piše kako su dosadašnji istraživači uočili sličnost između Misala i Epistolara te zaključili kako su ta dva kodeksa vjerojatno djelo istog majstora, dok je Evanđelistar djelo druge ruke, što je zaključak pomalo olako donesen. ${ }^{27}$ Zaista, dekorativni repertoar Evanđelistara kao i figuralne dionice (osim medaljona s prikazom sv. Krševana) na već objašnjen način pokazuju stilsku razliku i od Misala i od Epistolara. Međutim, što se tiče druga dva kodeksa, J. Kolanović zaključuje u jednoj rečenici o sličnostima ukrašavanja inicijala u Misalu i Epistolaru precizirajući da pri tome misli na dekorativno ukrašavanje i to onaj dio $\mathrm{u}$ »kome ukrasi izviru iz inicijala i protežu se cijelom stranom završavajući u pravilu s tri spirale «. ${ }^{28} \mathrm{Ni}$ u jednom trenutku ne piše o stilskim sličnostima figuralnih prikaza kojih u Misalu ima i na drugim folijima, ne samo na prva dva koje $\mathrm{M}$. Pelc jedino spominje. Unutar sitnoslikarskih radionica figuralne prikaze najčešće radi jedan, a dekorativne ukrase drugi majstor, što ne mora biti slučaj; međutim, kod ova dva kodeksa u određenim detaljima postoji sličnost u inicijalnoj i marginalnoj dekoraciji, osobito u dekoraciji koja se spušta dijeleći dva stupca, ali postoji i razlika koja je još veća kad je riječ o figuralnim prikazima. Na Misalu, kako na prva dva, najraskošnija, tako i na nekim drugima, javljaju se dragulji ili poprsja u ovalima kao imitacija gema okruženi biserjem, te medaljoni s naturalističkim prikazima životinja, što nije slučaj s Epistolarom. U pogledu navedenih ukrasa, kao što su tondi s naturalističkim prikazima životinja, geme te čitav repertoar, Misal pokazuje sličnost s oslikanim stranicama Biblije Borsa d'Este, ${ }^{29}$ odnosno s dekoracijom ferrarske sitnoslikarske škole. ${ }^{30}$ Osobita se sličnost očituje u prikazu majmuna. Iako o Misalu možemo suditi samo po sačuvanim crno-bijelim fotografijama, dovoljno je kako bi se zamijetila mnogo veća kvaliteta u oblikovanju likova te veća

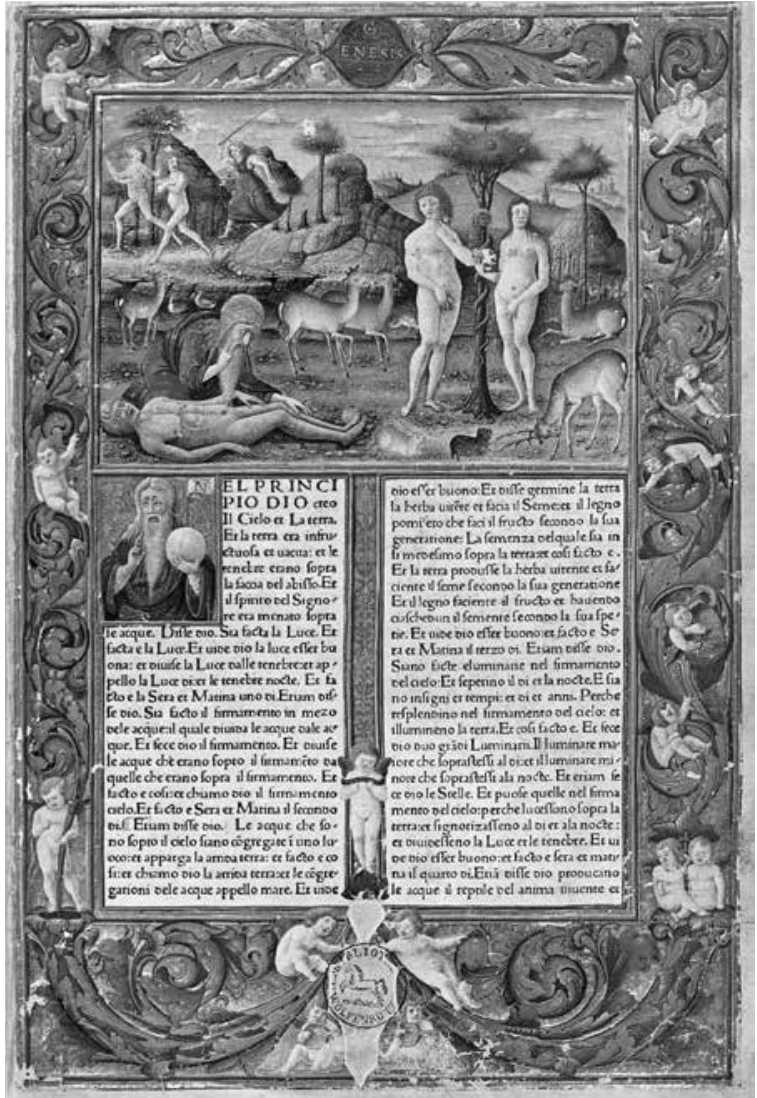

8. Usporedba s dekoracijom Evanđelistara: Franco dei Russi, Biblia Italica, Vindelius Spirensis, Venecija, 1471., Herzog August Bibliothek (Sig. $2^{\circ} 151$, vol. I., f. Ia) (preuzeto iz: Giordana Mariani Canova, La miniatura Veneta del Rinascimento, Alfieri, 1969.) / Comparation with the Evangelistary decoration: Franco dei Russi, Biblia Italica, Vindelius Spirensis, Venice, 1471, Herzog August Bibliothek (Sig. $2^{\circ} 151$, vol. I., f. Ia) (source: Giordana Mariani Canova, La miniatura Veneta del Rinascimento, Alfieri, 1969)

težnja volumenu, prostornosti i naturalizmu u odnosu na Epistolar. Ta je razlika osobita usporedimo li voluminoznost lika sv. Krševana na konju prikazanog unutar široke prostorne scene krajolika iz Misala s figurom sv. Pavla u Epistolaru koji je nevještim crtežom izveden dosta ukočen, frontalan, bez smisla za pokret te prikazan unutar, još u određenoj mjeri stiliziranog krajolika. Iako na Misalu ne možemo vidjeti boje, prema opisu koji donose stariji istraživači, ${ }^{31}$ bliskost lika sv. Krševana na konju sa srodnim likovima iz opusa Vittorea Carpaccia, s kojim ga i G. Sabalich uspoređuje, čini se mnogo uvjerljivijom. ${ }^{32}$ Pri tome se u prvom redu misli na stilsku srodnost i razinu izvedbe. Ona je osobito vidljiva pri usporedbi prikaza konja, dekoracije njegove orme, Krševanove junačke poze s kopljem pa i krajolika sa sv. Jurjem koji ubija zmaja na Carpacciovoj slici iz Scuole di San Giorgio degli Schiavoni u Veneciji gdje je svetac također prikazan bez kacige. Osim navedenoga, određena sličnost očituje se i u fizionomiji te načinu oblikovanja kose sv. Krševana. Prema usporedbama u radu M. 


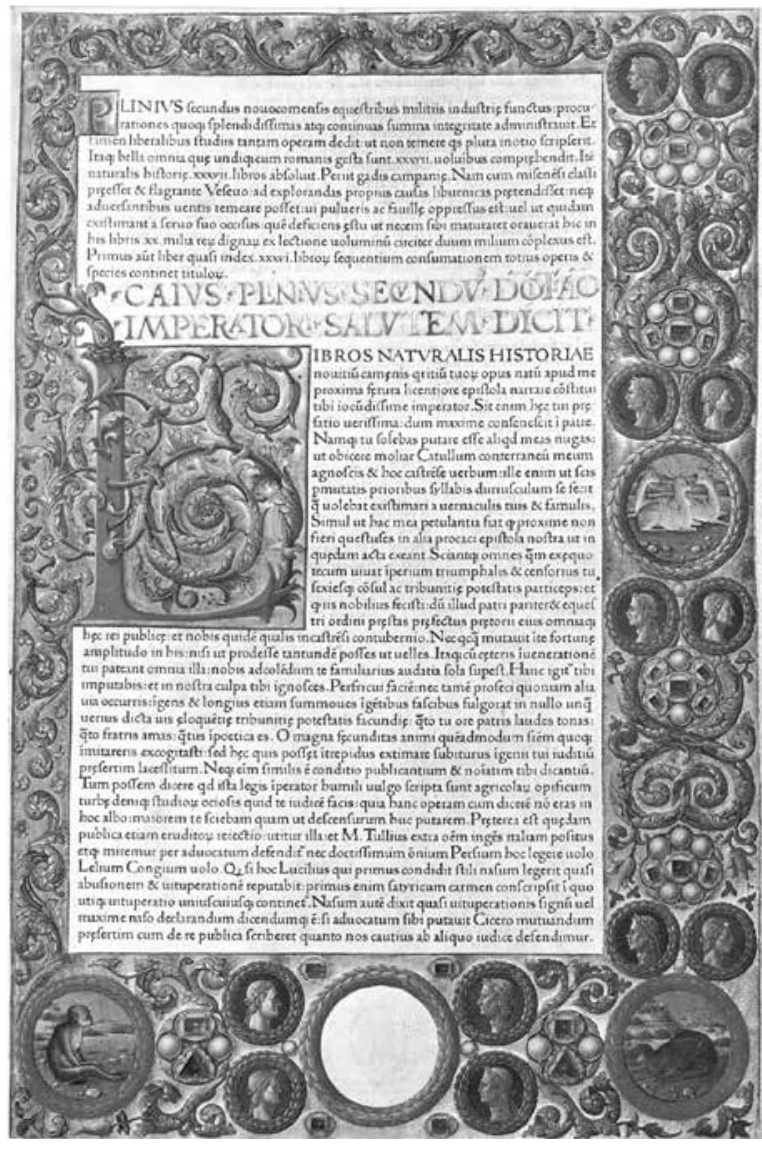

9. Usporedba s dekoracijom Misala: Girolamo da Cremona, Plinius Secundus, Naturalis Historia, Johanes Spirensis, 1469., Österreichische Nationalbibliothek, Beč, Inc. 3 C. 7, f. Ia (preuzeto iz: Giordana Mariani Canova, La miniatura Veneta del Rinascimento, Alfieri, 1969.) / Comparation with the Missal decoration: Girolamo da Cremona, Plinius Secundus, Naturalis Historia, Johanes Spirensis, 1469, Österreichische Nationalbibliothek, Vienna, Inc. 3 C. 7, f. Ia (source: Giordana Mariani Canova, La miniatura Veneta del Rinascimento, Alfieri, 1969)

Pelca, ${ }^{33}$ sličnost iluminacija u Misalu s opusom Picova Majstora najviše dolazi do izražaja u pogledu dekoracije bordura, iako se isti dekorativni repertoar može dovesti u vezu s oslicima unutar Biblije Borsa d'Este, ${ }^{34}$ na kojoj je radilo više majstora, kao, u krajnjoj liniji, i s još niz drugih djela i majstora iz toga vremena koji su imali doticaja s ferrarskom sitnoslikarskom radionicom. Primjerice, majstor Martino da Modena također koristi sličan dekorativni repertoar, što se osobito vidi na njegovu djelu Sv. Juraj i zmaj (Antifonario VII, c. 5v). ${ }^{35}$ Sličan dekorativni repertoar koristi i minijaturist Jacopo Filippo Medici zvan l'Argenta, ${ }^{36}$ dok se najsličnija dekoracija s prikazima majmuna, gema i bisera, po kojoj se Misal razlikuje od Evanđelistara i Epistolara, može uočiti na dekorativnom opusu Girolama da Cremone. ${ }^{37}$ Vrlo sličan repertoar pojavljuje se na foliju 1 njegova oslikanog Pliniusa Secundusa, Naturalis Historia ${ }^{38}$ te na foliju 239 Brevijara $^{39}$ oslikanog od strane Antonija Marije Sforze koji u određenoj mjeri koristi sličan reperto-

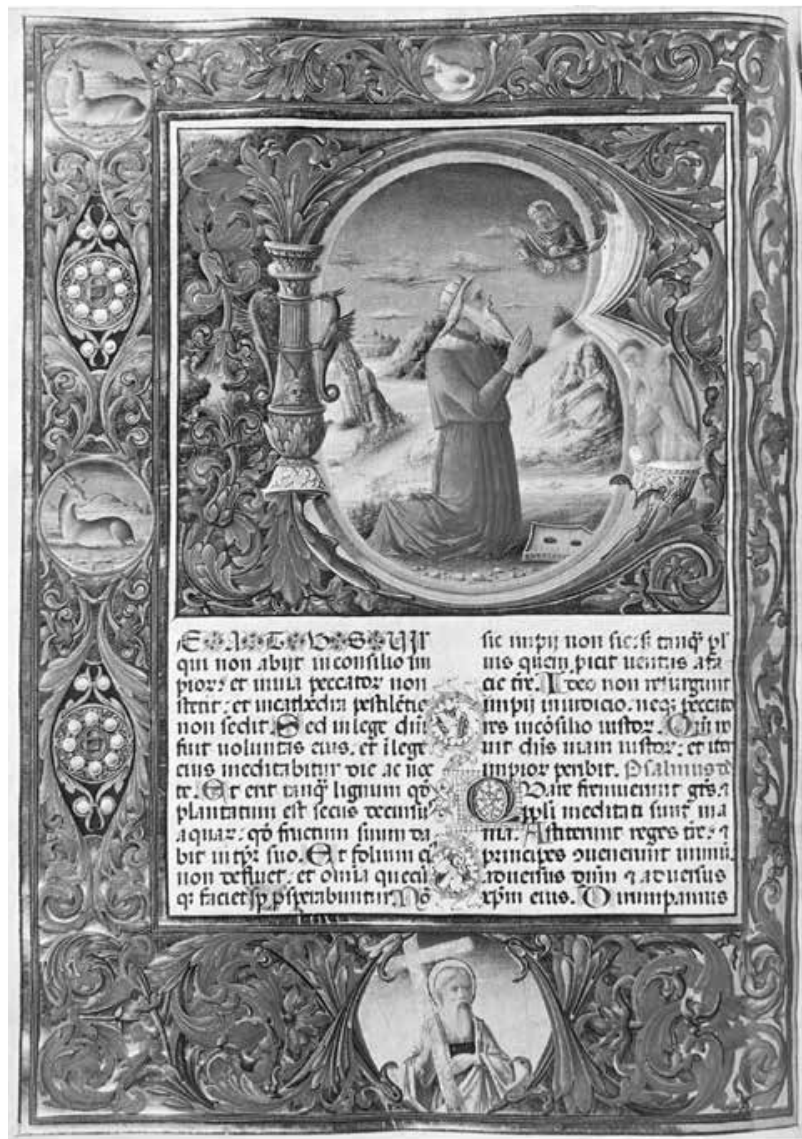

10. Antonio Maria Sforza, Breviarium, Bodleian Library, Oxford (Ms. Douce 314, f. 239b) (preuzeto iz: Giordana Mariani Canova, La miniatura Veneta del Rinascimento, Alfieri, 1969.) / Antonio Maria Sforza, Breviarium, Bodleian Library, Oxford (Ms. Douce 314, f. 239b) (source: Giordana Mariani Canova, La miniatura Veneta del Rinascimento, Alfieri, 1969)

ar. Dodirne točke s opusom Picova Majstora najviše dolaze do izražaja na Epistolaru, osobito u načinu na koji je krajolik rastvoren u donjem marginalnom polju sa zlatnom vazicom u lijevom kutu iako se takav način oblikovanja marginalnog prostora također susreće i kod nekih drugih iluminatora iz istoga sitnoslikarskog kruga. Picov Majstor se najvjerojatnije školovao u ferrarskom krugu, međutim, način modeliranja figuralnih dionica koje mu se pripisuju, bliži je mletačkom. Iako ne u tolikoj mjeri kao na Evanđelistaru, na Epistolaru se uočava, također, neprirodno lomljene draperije pod pravim kutom što nije slučaj na djelima Picova Majstora kod kojega pratimo nježnije oblikovanje te detalje oblikovane sitnim bijelim linijama. Dakle, premda neki elementi govore u prilog sličnosti s opusom Picova Majstora, znači li to nužno da je on autor tih iluminacija ili je možda autor zadarskih iluminacija naprosto radio prema istim predlošcima, odnosno koristio repertoar karakterističan za kraj 15. stoljeća svoje sredine? Osim oslika u Episto- 

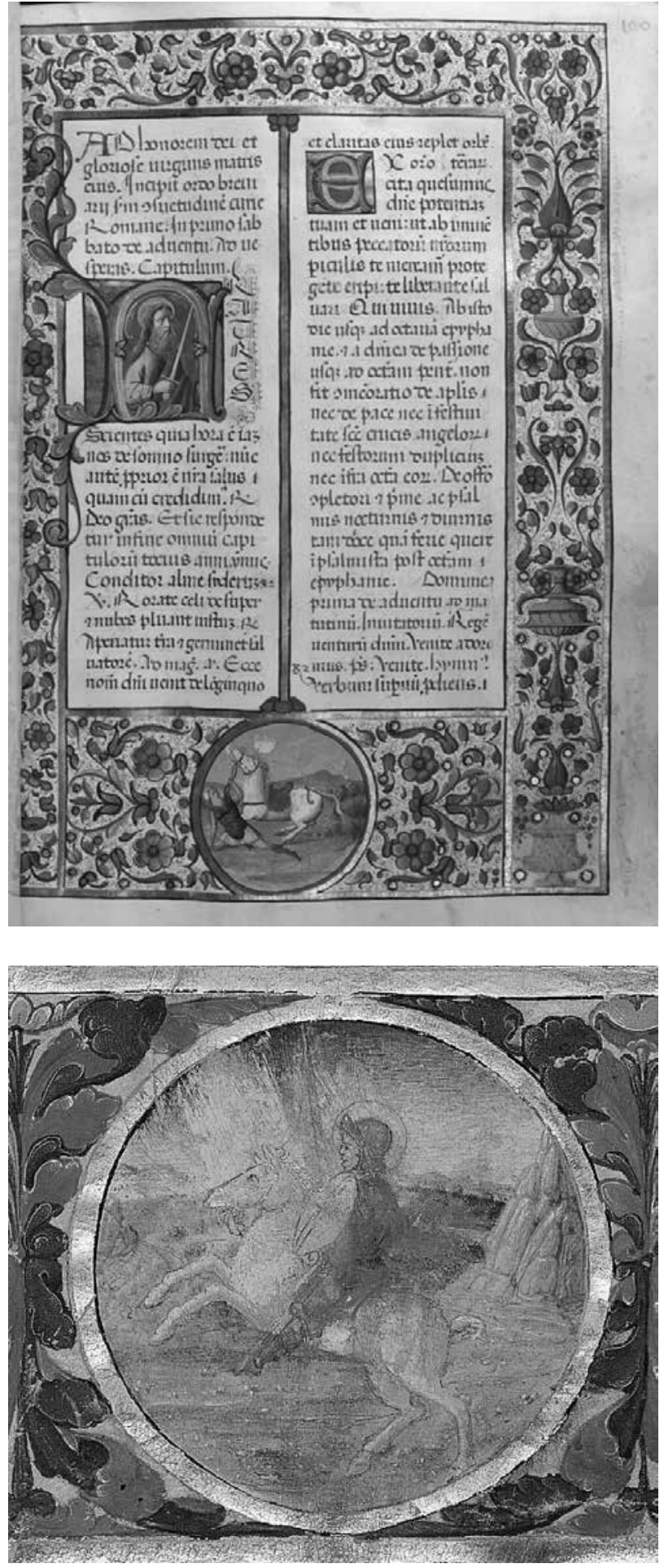

11. Usporedba detalja: detalj tonda iz Evandelistara s tondom na foliju u Brevijaru Benedeta Bordona, Venecija, 1480., Walters Art Museum, Baltimore (izvor: http://art.thewalters.org/detail/24877/ leaf-from-breviary-123/; 22. 9. 2013.) / Detail of the Evangelistary tondo compared to the tondo on the folio of the Breviary of Benedetto Bordon, Venice, 1480, Walters Art Museum, Baltimore (source: http:// art.thewalters.org/detail/24877/leaf-from-breviary-123/, 22 September 2013) laru, ruci Picova Majstora M. Pelc pripisuje i scenu sa sv. Krševanom u medaljonu Evanđelistara ${ }^{40}$ što je prihvatljivo, jer pokazuju i međusobnu srodnost, dok je figuralne dionice Misala na folijima 1 i 2, koje mu autor također pripisuje, izradio očito neki drugi, puno kvalitetniji mletački majstor, a ne Picov Majstor. To se prije svega odnosi na scenu sa sv. Krševanom na konju, oslike u tondima te čitavu marginalnu dekoraciju koja je, kao što je već isticano, puno bliža opusu Girolama da Cremone nego Picova Majstora. Misal posjeduje i nekoliko littera historiata poznatih s crno-bijelih fotografija Hansa Folnesicsa i Giuseppea Sabalicha. U izvedbi pojedinih bogatije figuralno izvedenih inicijala $\mathrm{H}$. Folnesics je uočio razlike što kasnije prenosi i J. Kolanović, te razabire četiri prepisivača koji su ih izrađivali. Jednom majstoru pripisuje prvu i drugu, najraskošnije ukrašenu stranicu, držeći da se utjecaj toga majstora osjeti sve do folija 29. Folije $17 \mathrm{r}$ i $18 \mathrm{v}$ pripisuje drugom majstoru. Folij $38 \mathrm{r}$ pripisuje trećem majstoru, dok oslike od folija $47 \mathrm{r}$ do 56v pripisuje četvrtom majstoru koji je, sudeći prema opisu i sačuvanoj crno-bijeloj fotografiji figure sv. Pavla na foliju 47 r, najmanje vješt. ${ }^{41} \mathrm{G}$. Sabalich uz fotografije folija 1 i 2 donosi i fotografije folija s prikazom scene Poklonstva kraljeva i folija s prikazom Uzašašća. ${ }^{42} \mathrm{H}$. Folnesics donosi fotografije prvog i drugog folija te fotografije detalja inicijala s prikazom scene Rođenja na foliju 18v, detalj inicijala s prikazom Poklonstva kraljeva te fotografiju cijelog folija $47 \mathrm{r}$ s inicijalom unutar koga je oslikana figura sv. Pavla. ${ }^{43}$ Zanimljivo je da folij 38v s kompozicijom Poklonstva kraljeva u Misalu pokazuje sličnost sa scenom Poklonstva kraljeva, također unutar inicijala »E«, sačuvanog fragmenta Psaltira ${ }^{44}$ Franca dei Russija, ${ }^{45}$ koji je radio i na osliku prethodno spominjane Biblije Borsa d'Este. Osim navedene diferencijacije iluminatorskih ruku prema nabrojenim folijima, općenitije gledano, slikara koji je iluminirao prvu i drugu stranicu, a čiji se utjecaj osjeća do folija 29, možemo okarakterizirati kao mletačkog majstora koji radi u ferrarskom sitnoslikarskom krugu. Potonji stil pokazuje marginalna dekoracija, a konačno i ostali foliji drugog, trećeg i četvrtoga prepoznatog majstora, koji ne pokazuju toliko mletačkih karakteristika. M. Pelc uspoređuje i iluminacije u Evandelistaru s majstorom Leonardom Bellinijem ${ }^{46}$ koji također pokazuje neke elemente bliske svetokrševanskim kodeksima. Naime, Leonardo Bellini koristi dekorativni repertoar blizak i Misalu, kao što uočavamo primjerice na dekoraciji bordure folija $5 \mathrm{u}$ djelu Promissione di Cristoforo Moro iz $1463 .{ }^{47}$ što ne govori mnogo s obzirom na to da u istoj mjeri srodnost pokazuje i dekorativna bordura na foliju 1 Biblie Italice Francesca dei Russija iz 1471. godine. ${ }^{48}$ $\mathrm{O}$ istoj razini sličnosti možemo govoriti kad je u pitanju dekoracija na foliju 5 oslikanog djela Promissione di Nicolo Tron ${ }^{49}$ Marsilija da Bologne te dekoracija folija 473 Brevija$r a^{50}$ Antonija Marije Sforze. Premda majstor, s obzirom na ambijent u kojem se kreće, dolazi u obzir kao mogući autor, 
primjećuju se razlike prema kojima to očito nije ni u pogledu figuralnih dionica. Sličnost koja postoji može implicirati samo poznavanje i kretanje u istim ili bliskim sitnoslikarskim krugovima. Dok je rad majstora u Evanđelistaru oštriji i tvrđeg crteža te življih i ekspresivnijih boja, očito je da opus Leonarda Bellinija, a osobito na usporedbi koju donosi M. Pelc, ne koristi takvu paletu. Njegov način oblikovanja fizionomije odaje psihologizaciju koja na nekim radovima graniči čak s naivnošću. Na problematiku atribucije svetokrševanskih kodeksa Picovu Majstoru skrenuli bismo pozornost još i usporedbom sličnosti tonda sa sv. Krševanom na Evandelistaru s oslikanim tondom na foliju Brevijara ${ }^{51}$ nastalog u Veneciji i oslikanog od strane Benedetta Bordona. ${ }^{52}$ Sličnost se očituje u koloritu, načinu obrade figuralnih i pozadinskih dijelova kao i kompozicijskog rješenja. Osim što svetokrševanski kodeksi pokazuju srodnost sa slikarstvom Picova Majstora, ne može se poreći da u istoj mjeri pokazuju srodnost i s nizom drugih iluminatora čiji je stil bio u doticaju s ferrarskom sitnoslikarskom radionicom koja je svojedobno izvršila golem utjecaj, između ostaloga, i na području Veneta. Od ostalih zadarskih renesansnih iluminiranih rukopisa koji pokazuju stilske srodnosti s Misalom izdvaja se časoslov posvećen Blaženoj Djevici Mariji koji se nalazi u Znanstvenoj knjižnici u Zadru. O njegovu izvornom podrijetlu nema podataka, ali se zna da je pripadao fondu nekadašnje knjižnice Paravia koji je naslijedila današnja Znanstvena knjižnica. On, također, pokazuje odlike sjeverno-talijanske minijature, uglavnom mletačke i ferrarske. ${ }^{53}$ Također, postoje i podaci te fotografska crno-bijela snimka koji svjedoči o tome da su se u knjižnici zadarske gimnazije nekad nalazili još i korali ukrašeni u ferrarskom stilu, ${ }^{54}$ dok se primjerci vrlo reprezentativnih rukopisa nastalih $\mathrm{u}$ tom stilu čuvaju u Riznici katedrale u Splitu. ${ }^{55}$

\section{BILJEŠKE}

* Rad je nastao na osnovi diplomskog rada obranjenog na Odjelu za povijest umjetnosti Sveučilišta u Zadru te nagrađenog nagradom »Radovan Ivančević« Društva povjesničara umjetnosti Hrvatske za najbolji diplomski rad u 2013. godini.

1 Rođeni Zadranin i rođak nadbiskupa Lorenza Veniera.

2 EDUARD PERIČIĆ, Samostan svetog Krševana kroz lik i djelovanje njegovih opata, u: Tisuću godina samostana svetog Krševana u Zadru, (ur.) Miroslav Granić, Stijepo Obad, Ivo Petricoli, Narodni list, Zadar, 1990., 104-105.

3 NIKICA KOLUMBIĆ, Zadarski humanistički krug u okviru samostana svetog Krševana, u: Tisuću godina samostana svetog Krševana u Zadru, (ur.) Miroslav Granić, Stijepo Obad, Ivo Petricoli, Narodni list, Zadar, 1990., 149.

4 EDUARD PERIČIĆ (bilj. 2), 107.

5 Psaltiri »M« $\mathrm{i}$ »L koji se čuvaju u knjižnici samostana sv. Frane te Matrikula bratovštine pomoraca i ribara sv. Andrije i Časoslov Blažene Djevice Marije koji se nalaze u Znanstvenoj knjižnici u Zadru.

6 EMIL HILJE, RADOSLAV TOMIĆ, Umjetnička baština Zadarske nadbiskupije - Slikarstvo, Zadarska nadbiskupija, Zadar, 2006., 190.
7 HERMAN JULIUS HERMANN, Die Handschriften und Inkunabulen der italienischen Renaissance, Leipzig, 1931.

8 EMIL HILJE, RADOSLAV TOMIĆ (bilj. 6), 193.

9 ANĐELKO BADURINA, Minijatura, Jugoslavija, Beograd, 1983.

10 TOMISLAV RAUKAR, IVO PETRICIOLI, FRANJO ŠVELEC, ŠIME PERIČIĆ, Zadar pod mletačkom upravom, Prošlost Zadra III, Narodni list, Zadar, 1987.

11 JOSIP KOLANOVIĆ, Liturgijski kodeksi svetokrševanskog opata Deodata Veniera, Radovi Zavoda JAZU u Zadru, 29-30 (1983.), 57-84.

12 EMIL HILJE, RADOSLAV TOMIĆ (bilj. 6), 2006.

13 MILAN PELC, Picov Majstor i kodeksi zadarskog opata Deodata Veniera, Radovi Instituta za povijest umjetnosti, 36 (2012.), 113-124.

14 GIUSEPPE SABALICH, Le miniature antiche di Zara, Zadar, 1909.

15 HANS FOLNESICS, Die illuminierten Handschriften in Dalmatien, Leipzig, 1917.

16 EMIL HILJE, RADOSLAV TOMIĆ (bilj. 6), 195.

17 TOMISLAV RAUKAR, IVO PETRICIOLI, FRANJO ŠVELEC, ŠIME PERIČIĆ (bilj. 10).

18 JOSIP KOLANOVIĆ (bilj. 11).

19 EMIL HILJE, RADOSLAV TOMIĆ (bilj. 6).

20 HANS FOLNESICS (bilj. 15); JOSIP KOLANOVIĆ (bilj. 11); EMIL HILJE, RADOSLAV TOMIĆ (bilj. 6).

21 JOSIP KOLANOVIĆ (bilj. 11), 64.

22 Ibid.

23 Franco dei Russi, Biblia Italica, Vindelius Spirensis, Venezia, 1471., Herzog August Bibliothek (Sig. $2^{\circ} 151$, vol. I, f. Ia).

24 MILAN PELC (bilj. 13), 114.

25 Usporedbe tekstova vidjeti u: JOSIP KOLANOVIĆ (bilj. 11), 63.

26 JOSIP KOLANOVIĆ (bilj. 11), 162-163.

27 MILAN PELC (bilj. 13), 115.

28 Istu misao obrazlaže čak dvaput na dvije stranice: JOSIP KOLANOVIĆ (bilj. 11), 64, 69.

29 Biblija Borsa d'Este dobila je naziv prema ferrarskom vojvodi Brosu d'Este i djelo je više iluminatora od kojih su važniji Taddeo Crivelli i Franco dei Russi. Nastala je u razdoblju od 1455. do 1461. godine, a čuva se u Biblioteci Estense u Modeni (Ms. Lat. 422-423), URL: http://www. wdl.org/en/item/9910/view/1/1/ (19. 6. 2013.).

30 HERMAN JULIUS HERMAN, La miniatura Estense, Modena, 1994.

31 H. Folnesics i G. Sabalich.

32 GIUSEPPE SABALICH (bilj. 14), 20.

33 MILAN PELC (bilj. 13).

34 Biblioteca Estense u Modeni (Ms. Lat. 422-423); URL: http://www. wdl.org/en/item/9910/view/1/1/ (19. 6. 2013.).

35 Martino da Modena, Antifonario VII, c. 5v, Sv. Juraj i zmaj, Muzej katedrale, Ferrara (1478.-1486.), URL: http://www.artecultura.fe.it/1766/ percorso-espositivo (19. 6. 2013.)

36 Minijaturist aktivan na području Ferrare i Bologne na samom kraju 15. i početku 16. stoljeća. Detaljnije vidjeti u: Il rinascimento in Italia, The National Museum of Western Art, Tokyo, 2001., 124.

37 GIORDANA MARIANI CANOVA, La miniatura Veneta del Rinascimento, Alfieri, 1969., 117-122.

38 Plinius Secundus, Naturalis Historia, Johannes Spirensis, Venezia, 1469., Nationalbibliothek, Wien (Inc. 3. C. 7, f. Ia)

39 Breviarium, Bodleian Library, Oxford (Ms. Douce 314, f. 239b).

40 MILAN PELC (bilj. 13).

41 HANS FOLNESICS (bilj. 15), 3; JOSIP KOLANOVIĆ (bilj. 11), 67.

42 GIUSEPPE SABALICH (bilj. 14), cartella 18 i 19.

43 HANS FOLNESICS (bilj. 15).

44 Dei Russi, Inicijal "E«, Poklonstvo kraljeva, J. Paul Getty Museum, L. A., SAD, MS. 83, RECTO, URL: http://www.getty.edu/art/gettyguide/ artObjectDetails?artobj=253200 (19. 6. 2013.).

45 GIORDANA MARIANI CANOVA (bilj. 37), 104-106.

46 MILAN PELC (bilj. 13).

47 British Museum, London (Add. Ms 15186, f. 5a). 
48 Vindelinus Spirensis, Venezia, 1471., Herzog August Bibliothek, Wolfenbüttel (Slg. $2^{\circ} 151$, vol. II, f. Ib.).

49 Spencer Collection, The New York Public Library (Ms. 40, f. 5).

50 Bodleian Library, Oxford (Ms. Douce 314, f. 473b).

51 Brevijar, nastao u Veneciji 1480., čuva se u Walters Art Museumu, Baltimore; URL: http://art.thewalters.org/detail/24877/leaf-from-breviary-123/ (22. 9. 2013.).

52 GIORDANA MARIANI CANOVA (bilj. 37), 68-75, 122-130.

53 FEDERICA TONIOLO, Manoscritti miniati di area veneta e padana nelle biblioteche della Croazia: alcuni esempi dal XIII. al XVI. secolo, u:
Književnost, umjetnost, kultura između dviju obala Jadrana. Zbornik radova s međunarodnog znanstvenog skupa Zadar-Nin, (ur.) Guido Baldassarri, Nikola Jakšić, Živko Nižić, Zadar, 2008., 201-218.

54 LJUBO KARAMAN, Umjetnička oprema knjige u Dalmaciji, Hrvatska revija, 7 (1933.), 414.

55 -, Slikarstvo, u: Split Marulićevog doba, katalog izložbe, (ur.) G. Borčić, Muzej grada Splita, 22. 11. 2001. - 11. 1. 2002., Split, 2001., 47-55, $180-186$.

Summary

Ana Šitina

\section{New Reflections on the Codices of the Zadar Abbot Deodat Venier}

The article discusses four codices produced for the monastery of St Chrysogonus in Zadar in late $15^{\text {th }}$ century, commissioned by Abbot Deodat Venier for liturgical purposes. Although the actual context of their creation remains unknown, earlier illuminated manuscripts surveys associated the codices with Venetian miniaturist circle, whereas new studies propose the connection with the oeuvre of the Pico Master. The author draws attention to the similarities of Zadar illuminations to the Ferrara school of illumination, especially in relation to the decorative repertoire, as well as to the problems arising from their association to specific illuminators considering that no clear data which would indicate a concrete artistic personality have thus far been revealed, and that preserved works indicate common features only on a more general level. Drawing on the scarce data provided by the artwork itself, as well as on the stylistic and comparative analysis of similar works, the author argues that the Evangelistary and the Epistolary originate from the same workshop, proposing the attribution of the Epistolary to the same master who finished the illumination of the Evangelistary medallion. The Missal, on the other hand, is stylistically removed from the aforementioned two codices, so the figurative sections of their cover pages (fols. 1 and 2) are considered to be the work of another, more skilled Venetian master working under the influence of Vittore Carpaccio's painting, while the influence of Ferrara is discerned not only on the decorative repertoire on the margins, typical for the said circle, but also on other illuminated litterae historiatae. Unlike the said three codices, the Ceremonial contains no preserved figurative illuminations, but only litterae dominicales, while a richly illuminated cover page can only be assumed due to the inexistence of its first folio. 
